\title{
Colloque Victor Gelu: Marseille au XIXe siècle, Université de Provence-Marseille
}

\author{
Edgar Leon Newman
}

New Mexico State University

Regionalism and popularism were the dominant themes at the Colloque Victor Gelu, organized at the Université de Provence-Marseille by the Regional Center for Occitan Studies October 25-27, 1985 to mark the hundredth anniversary of the death of Victor Gelu (1806-85), the Marseillais songwriter and poet. As if to set the tone for the conference, a poster on the walls of the starkly functional Université de Provence-Marseille said: "No to Atlantic France!" One participant was so carried away be the spirit of the colloquium that he would speak only in Provençal. The conference opened with a poem in Provençal by Jorge Reboul, followed by J. Boisseau's paper on Marseille's resistance to the protectionist Méline tariffs in the 1890s. Boisseau quoted the newspaper Le Sémaphore de Marseille, which had gone so far as to say that Marseille is "a separate republic," not an appendage of France. In part, this local resentment of the tyranny of Paris was a legacy of Victor Gelu.

J. Arrouye, speaking on "Moral Geography in [Victor Gelu's novel] Novè Granet, written in 1856, noted how Gelu had portrayed Paris as rich and evil, and Marseille as poor and good. Unlike Balzac's characters, who found Paris irresistible and who let it lure them to their spiritual deaths, Gelu's hero hates Paris and returns to Marseille as soon as he can. Gelu's hero, and Gelu himself, detested everything that Paris stood for: urbanization, capitalism, materialism, mechanization, speculation. He wanted a world in which there were no machines and the workers had work.

Gelu's ideals came from his memories of the Marseille of his youth. His family was moderately wealthy, but he preferred to spend his time with the working people. According to Lucien Gaillard of the Université de ProvenceMarseille, a leading expert on Gelu and on popular mentality in nineteenthcentury Marseille, young Gelu had known among the workers only the Marseille dockers, the portefaix de Marseille, whose exclusive corporation gave them spectacularly high wages and an iron grip on the loading and unloading of ships. The portefaix de Marseille had no desire to see their city mechanized; they could keep their jobs only so long as the port needed the sacks on their backs to unload its ships. Gelu shared their Luddist point of view, and he opposed schemes of mechanization all his life. He also opposed all of the social

International Labor and Working-Class History

No. 31, Spring 1987, pp. 93-95

(C) 1987 by the Board of Trustees of the University of Illinois 
groups that made mechanization possible: speculators, capitalists, especially Americans, who were known for their materialism and love of machines. A strident anti-Semite, he heaped special blame on Jews for mechanization. An admirer of Rousseau, Gelu was a Rousseau democrat in politics, but his political ideas were poetic rather than rational. He had been accidentally wounded in Lyon during the uprising of the silkworkers in 1831, and he sympathized with them and called the soldiers who put down their revolt "cowardly assassins." He saw fatherhood as the ultimate moralizing force, and he suggested that in a democracy only fathers should have the right to vote. He wanted education for all the people and effective child labor laws, and he criticized the 1831 law on child labor as worthless. He was furious when gas was installed in Marseille in 1838 and the resulting pollution put the fishermen out of work. In 1854 , he opposed the Crimean War because he believed it was killing off only young working-class men. Gelu described his political ideas this way: "I am a socialist like Chateaubriand and like the late Duc D'Orléans, whose departure I regret."

Roland Caty's paper continued this discussion of Gelu's quirky political ideas. Caty noted that Gelu had been opposed to gas because it polluted the water, and he concluded that Gelu was a precursor of our modern ecology movement. Gelu's sympathy for the workers made him hostile to agricultural machines, which were putting agricultural laborers out of work, and to railroads, which were destroying the traditional economy and tearing up the countryside. Gelu believed that machines only made the rich richer and the poor poorer. A traditionalist, he preferred the slow-moving, corporative Marseille of the 1815-30 Bourbon Restoration. If it were up to Gelu, The Bourse would be closed, and all Jews sent to Asia or exterminated.

As the conference progressed, it became increasingly clear that Victor Gelu is a hero both inside and outside the academic world because he was close to the people and a proud Provençal. On Friday, October 25, people from all walks of life attended the unveiling of a commemorative plaque dedicated to the memory of Gelu. On Saturday evening, October 26, the general public joined the conference participants in attending a performance of Gelu's Provençal songs at the Escoutille Theater. Marseille television, which is systematically setting aside time for programs in Provençal, took an interest in the colloquium and broadcast an interview of some of the participants. Gelu's status as a hero is hard to miss; his statue is the only monument in the square near the Old Port.

Also at the Old Port and close to Gelu's statue is a spot where a large block of buildings was torn down by the Nazis during World War II and all of their occupants sent to concentration camps. It seems ironic that the antimodernist, anti-Semitic Gelu should be remembered so fondly. Certainly he cannot be ignored; his poetry and songs ring with the love he had for ordinary people and make the popular culture of nineteenth-century Marseille come 
alive. The growing Occitan movement sees Gelu as a defender of the language and culture of Marseille, and his poems, like the striking Fenian e grouman (The Lazy Man and the Glutton) and the touching Lou Crèdo dé Cassian (Cassian's Credo), now available as recordings, show why Gelu so dominated the popular theaters of nineteenth-century Marseille. His art and his ideas lie at the roots of contemporary Occitan culture and populist ideology. But some of those roots are poisonous. 